\title{
HISTOPATHOLOGICAL CHANGES IN BRAIN, KIDNEY AND LIVER OF MICE FOLLOWING INTRAMUSCULAR ADMINISTRATION OF KRAIT VENOM
}

\author{
D. P. Nanayakkara ${ }^{1}$, R. M. P. Ratnayake ${ }^{2}$ and J.G. Shirani Ranasinghe ${ }^{3 *}$ \\ ${ }^{1}$ Department of Anatomy, Faculty of Medicine, University of Peradeniya, Sri Lanka \\ ${ }^{2}$ Teaching Hospital, Kurunagala, Sri Lanka \\ ${ }^{3}$ Department of Biochemistry, Faculty of Medicine, University of Peradeniya, Sri Lanka \\ Accepted 03 May 2009
}

\begin{abstract}
Histopathological changes following krait (Bungarus) bites are not widely documented compared to other species of snakes. In this study, the histopathological changes in liver, kidney and brain tissues following intramuscular administration of venom of Bungarus ceylonicus and Bungarus caeruleus were studied. Serial dilutions of venom of the two species of snakes were injected to seven groups of mice after determination of protein concentrations. There were no macroscopically identifiable changes in any of the organs. Tissues were obtained for histological studies at $1 \mathrm{~h}, 3 \mathrm{~h}, 6 \mathrm{~h}, 12 \mathrm{~h}$ and $24 \mathrm{~h}$ time intervals following injection of venom. Histopathological changes namely congestion, inflammation and necrosis were observed microscopically in the tissues of liver, brain and kidney. These changes were proportionate to the dose of venom and were maximum in the liver at the dose of $1.0 \mu \mathrm{g} /$ mouse for $B$. caeruleus venom and at $2.0 \mu \mathrm{g} /$ mouse for B. ceylonicus venom. Histopathological changes observed due to B. caeruleus and B. ceylonicus venom appeared within $1 \mathrm{~h}$ in all tissues. Congestion was moderate in the liver and kidney but was less marked in brain. Inflammatory infiltration was seen in the perivascular regions in liver and kidney and was mainly lymphocytic. Venom of B. ceylonicus produced histopathological changes in the brain tissue, but not B. caeruleus venom. Histopathological changes were intense with B. ceylonicus venom than with B.caeruleus venom. Necrosis was seen in the liver and brain only following administration of B. ceylonicus venom. No histopathological changes were observed in skeletal and cardiac muscle with either venom.
\end{abstract}

Key words: Bungarus ceylonicus, Bungarus caeruleus, inflammatory infiltration, congestion, necrosis

\section{INTRODUCTION}

Tissue changes following snake envenomation depend on the species of snake responsible for the bite, the composition of its venom and also the susceptibility of the tissue for a particular component of the venom (Kamiguti et al., 2000). Snake venom affects the kidneys more frequently than the other tissues. This is more pronounced when there is haemotoxins and vasculotoxins in venom. Renal manifestations are very common following viper bites (Sheriff, 1983). Histologically, changes due to viper venom have been seen in all renal structures (Soe et al., 1993). Degeneration, necrosis and regeneration of tubular epithelial cells are seen in renal tubules. Interstitial oedema, cellular infiltration, arteritis, thrombophlebitis, congestion, infarction and cortical necrosis have also been observed (Sitprija, 2006; Kiran et al., 2004).
In the liver, congestion and petechial haemorrhages, microvescicular fatty change, hydropic degeneration as well as necrosis of hepatocytes have been recorded following snake bites (de Silva et al., 1992; Kumaranayake, 1971).

Myocardial changes are common when snake venom is rich in cardiotoxins. Congestion of myocardial blood vessels and petichial haemorrhages are the frequent histological manifestations. Skeletal muscles are affected in the presence of myotoxic substances in the venom. Microscopically, congestion of blood vessels and necrosis are the common findings. Indirectly, muscle damage results in myoglobinuria which could be detected biochemically (Ali et al., 2000).

Histological changes in the brain tissues following snake bites are not widely documented

*Corresponding Author’s email: shirani05@yahoo.com 
compared to other organs. However, since snake venom is rich in neurotoxins significant microscopical changes are likely to be present in the brain tissue. Multiple small foci of haemorrhages and congestion of blood vessels have been reported following administration of collubrid snake venom to rats which was more marked with intravenous injection of venom (Peichoto et al., 2006). Apoptosis of Schwann cells following intramuscular injection of beta bungarotoxin has been demonstrated in chick embryos (Ciutat et al., 1996). In addition, histopathological changes have been demonstrated in the lungs and adrenal glands (Kularatne \& Ratnatunga, 2001). Bungarus venom is a rich source of phospholipases which break down phospholipids in the cell membrane. This is thought to be the most important mode of tissue damage in elapid snake bites (Sitprija, 2006).

The objective of this study was to identify and compare the histological changes in liver, brain and kidney tissues following intramuscular injection of $B$. ceylonicus and B. caeruleus venom to mice.

\section{MATERIALS AND METHODS}

For the collection of venom, three snakes of each of the two species, $B$. caeruleus and B. ceylonicus were used. Venom was collected on three consecutive days and the protein concentration of venom determined by the method of Lowry (Lowry et. al., 1851). Next, venom was diluted with freshly prepared phosphate buffered saline at $\mathrm{pH} 7.2$ and injectable samples were prepared and stored at $80^{\circ} \mathrm{C}$ up to a period of 12 weeks.

Three to six month old Balb $\mathrm{C}$ mice weighing 25-30 g were used as the mammalian model. Seven groups of thirty mice were used with equal numbers of males and females.

Aliquots of $0.5 \mathrm{ml}$ of venom from $B$. caeruleus and B. ceylonicus at concentrations shown in the Table 1 were injected to the left thigh of mice intramuscularly. The strength of venom used was based on the $\mathrm{LD}_{50}$ values for B. caeruleus (Ranasinghe, 1983). Control group was administered with $0.5 \mathrm{ml}$ of freshly prepared phosphate buffered saline.

At $1 \mathrm{~h}, 3 \mathrm{~h}, 6 \mathrm{~h}, 12 \mathrm{~h}$ and $24 \mathrm{~h}$ following administration of venom into mice, six mice from each treatment group were anaesthetized and liver, kidneys, brain, heart and the right thigh muscle were removed and preserved in $10 \%$ formalin. Paraffin sections were prepared and stained with Haematoxylin and Eosin and assessed under light microscopy by two individuals. Histopathological changes were scored according to a predetermined system given in Table 2. If three out of six mice in a treatment group showed a particular histological change it was considered as a positive response.

Table 1. Type and protein content of Bungarus venom injected in to mice

\begin{tabular}{lll}
\hline Group No. & Venom protein content & Type of venom \\
\hline 1 & $0.5 \mu \mathrm{g}$ & $\begin{array}{l}\text { B. caeruleus } \\
\text { B. ceylonicus }\end{array}$ \\
4 & & B. caeruleus \\
2 & $1 \mu \mathrm{g}$ & B. ceylonicus \\
5 & & B. caeruleus \\
3 & $2 \mu \mathrm{g}$ & B. ceylonicus \\
6 & & \\
7 (control) & $0.5 \mathrm{ml}$ phosphate buffered saline & \\
\hline
\end{tabular}


Table 2. Histopathological changes in the tissues following envenomation of mice.

\begin{tabular}{|c|c|c|c|c|}
\hline Tissue change & Liver & Brain & Kidney & Score \\
\hline \multirow[t]{4}{*}{ Congestion } & No congestion & No congestion & No congestion & 0 \\
\hline & $\begin{array}{l}\text { In few sinusoids and } \\
\text { vessels }\end{array}$ & $\begin{array}{l}\text { In less than half of the } \\
\text { vessels }\end{array}$ & $\begin{array}{l}\text { In only a few } \\
\text { glomeruli and } \\
\text { interstitial vessels }\end{array}$ & + \\
\hline & $\begin{array}{l}\text { In about half of } \\
\text { sinusoids and vessels }\end{array}$ & $\begin{array}{l}\text { In about half of the } \\
\text { vessels }\end{array}$ & $\begin{array}{l}\text { In about half of the } \\
\text { glomeruli and } \\
\text { interstitial vessels }\end{array}$ & ++ \\
\hline & $\begin{array}{l}\text { In almost all sinusoids } \\
\text { and vessels }\end{array}$ & In almost all vessels & $\begin{array}{l}\text { In almost all } \\
\text { glomeruli and } \\
\text { interstitial vessels }\end{array}$ & +++ \\
\hline \multirow[t]{4}{*}{$\begin{array}{l}\text { Inflammatory } \\
\text { infiltration }\end{array}$} & $\begin{array}{l}\text { No inflammatory } \\
\text { infiltrate }\end{array}$ & $\begin{array}{l}\text { No inflammatory } \\
\text { infiltrate }\end{array}$ & $\begin{array}{l}\text { No inflammatory } \\
\text { infiltrate }\end{array}$ & 0 \\
\hline & $\begin{array}{l}\text { 1-3 inflammatory foci/ } \\
\text { section }\end{array}$ & $\begin{array}{l}<20 \text { inflammatory cells } \\
\text { /HPF }\end{array}$ & $\begin{array}{l}1-3 \text { inflammatory } \\
\text { foci/ section }\end{array}$ & + \\
\hline & $\begin{array}{l}4-6 \text { inflammatory foci/ } \\
\text { section }\end{array}$ & $\begin{array}{l}>20 \text { inflammatory cells } \\
\text { /HPF }\end{array}$ & $\begin{array}{l}\text { 4-6 inflammatory } \\
\text { foci/ section }\end{array}$ & ++ \\
\hline & $\begin{array}{l}>6 \text { inflammatory foci/ } \\
\text { section }\end{array}$ & & $\begin{array}{l}>6 \text { inflammatory } \\
\text { foci/ section }\end{array}$ & +++ \\
\hline \multirow[t]{4}{*}{ Necrosis } & No necrosis & No necrosis & & 0 \\
\hline & Focal necrosis & Focal necrosis & & + \\
\hline & Zonal necrosis & Extensive necrosis & & ++ \\
\hline & Confluent necrosis & & & +++ \\
\hline
\end{tabular}

\section{RESULTS}

No macroscopically identifiable changes were observed in any of the tissues of the mice. Histopathological changes were seen in the specimens of liver, brain and kidneys and not in skeletal and cardiac muscles of the treated mice. These histopathological changes were inflammatory, congestive and necrotic in nature. Inflammatory infiltrates consisted of lymphocytes and few plasma cells. Scattered inflammatory cells in the tissues were not considered positive.

Although architectural distortion of the liver was not a common feature, lobular disarray with hydropic change (Fig. 1A) was seen in few tissue samples (7\%) following administering
B. ceylonicus venom which was not seen with $B$. caeruleus. Congestion was seen in almost all tissue samples of liver (Fig. 1B) and kidney (Fig. 3A) following venom administration irrespective of the concentration, time duration since injection or the species of snake. In the kidney glomerular congestion was seen in tissues collected after 6h, 12h and 24h following administering venom but not after $1 \mathrm{~h}$ and $3 \mathrm{~h}$. Mild congestion of the meningeal vessels (Fig. 2A) was seen in the brain with B. ceylonicus venom but not with B. caeruleus venom.

Inflammatory infiltrates were confined to the periportal and perivenular regions of the liver following administration of both types of krait venoms (Fig. 1C and Table 3) and was 
prominent in tissues obtained $6 \mathrm{~h}, 12 \mathrm{~h}$ and $24 \mathrm{~h}$ after injection than in tissues obtained earlier (1h and 3h). Only one mouse in the control group showed evidence of inflammation. Liver necrosis (Fig. 1D) was a consistent finding following injection of $B$. ceylonicus venom which was not seen with $B$. caeruleus venom at any concentration. When necrosis was present, it was always associated with inflammatory infiltration and not vice versa. Periventricular focal necrosis with associated inflammatory

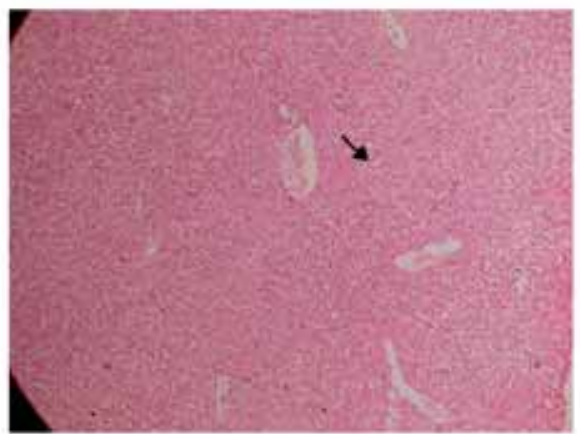

A (H\&E X $4 \times 10)$

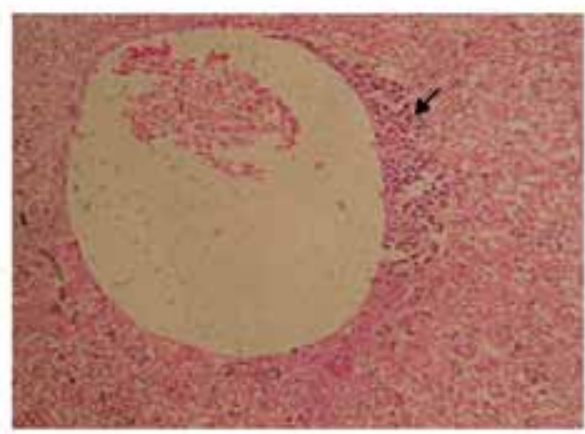

C $(\mathrm{H} \& \mathrm{E} \times 4 \times 60)$ infiltration was the most prominent feature in the cerebrum which was seen only following administration of B. ceylonicus venom (Fig. 2C and Table 4).

In the kidney inflammatory infiltrates were seen close to large arteries and veins (Fig. 3B and Table 5) but necrosis was not seen. Similar histopathological changes were seen in mice following administering both $B$. ceylonicus and B. caeruleus venom.

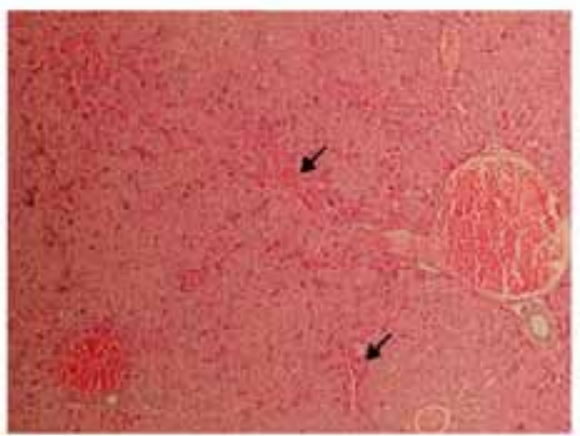

$B(H \& E \times 10 \times 10)$

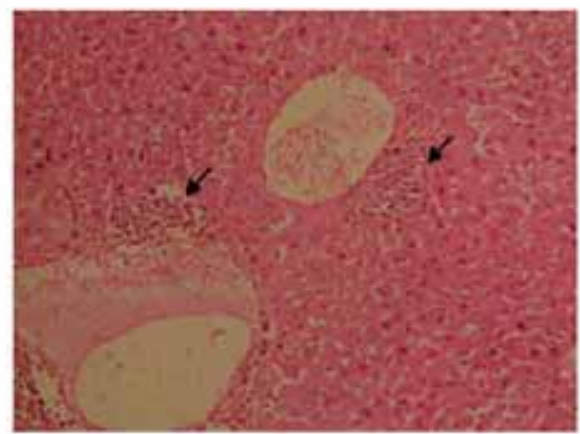

$D($ H\&E $\times 10 \times 10)$

Figure 1. Histopathological changes in liver tissue of mice following envenomation with $B$. ceylonicus venom: (A) Lobular disarray, (B) Congestion (arrows point to congested vessels), (C) Inflammatory foci (arrow points to an inflammatory focus adjacent to a central vein and (D) Focal necrosis (arrows point to two foci of necroinflammation). 


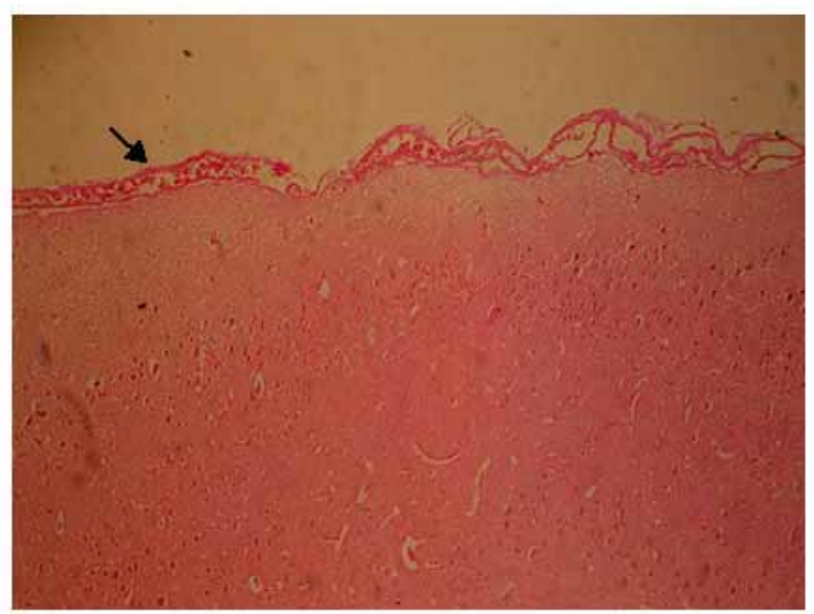

A $(\mathrm{H \& E} \times 4 \times 10)$

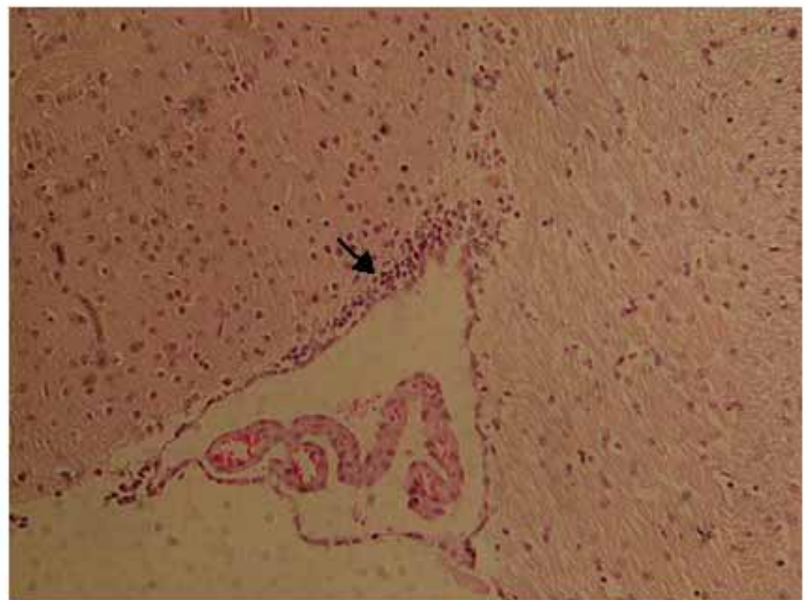

$B(\mathrm{H} \& \mathrm{E} \times 10 \times 60)$

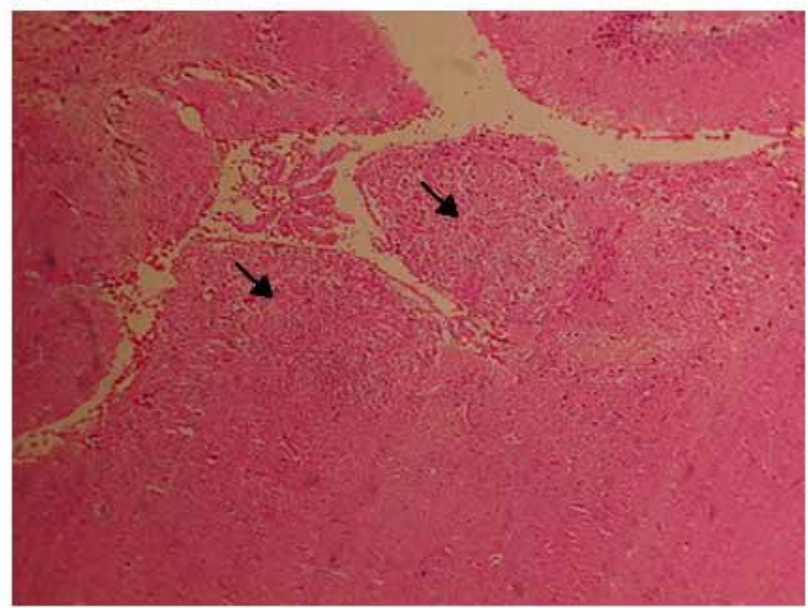

$C(\mathrm{H} \& \mathrm{E} \times 10 \times 60)$

Figure 2. Histopathological changes in brain tissue of mice following envenomation with $B$. ceylonicus venom: (A) Congestion (arrow points to a congested meningeal vessel), (B) Inflammatory foci (arrow points to a periventricular inflammatory focus) and (C) Necrosis (arrows point to two necrotic foci in the periventricular region). 
Table 3. Inflammatory infiltration and necrosis in liver in mice due to envenomation with different concentrations of $B$. ceylonicus (A) and B. caeruleus (B) venom.

\begin{tabular}{|c|c|c|c|c|c|c|c|}
\hline \multirow{3}{*}{$\begin{array}{l}\text { Time since } \\
\text { injection }\end{array}$} & \multirow{3}{*}{$\begin{array}{l}\text { Histopathological } \\
\text { feature }\end{array}$} & \multicolumn{6}{|c|}{ Venom Concentration } \\
\hline & & \multicolumn{2}{|c|}{$0.5 \mu g$} & \multicolumn{2}{|c|}{$1.0 \mu \mathrm{g}$} & \multicolumn{2}{|c|}{$2.0 \mu \mathrm{g}$} \\
\hline & & A & B & A & B & A & B \\
\hline \multirow[t]{2}{*}{$1 \mathrm{~h}$} & Inflammation & 0 & 0 & 0 & + & + & + \\
\hline & Necrosis & 0 & 0 & 0 & 0 & + & 0 \\
\hline \multirow[t]{2}{*}{$3 \mathrm{~h}$} & Inflammation & + & 0 & + & 0 & +++ & + \\
\hline & Necrosis & 0 & 0 & 0 & 0 & + & 0 \\
\hline \multirow[t]{2}{*}{$6 \mathrm{~h}$} & Inflammation & +++ & + & 0 & + & + & 0 \\
\hline & Necrosis & + & 0 & 0 & 0 & + & 0 \\
\hline \multirow[t]{2}{*}{$12 \mathrm{~h}$} & Inflammation & + & + & + & + & +++ & $\mathrm{N}$ \\
\hline & Necrosis & + & 0 & 0 & 0 & + & $\mathrm{N}$ \\
\hline \multirow[t]{2}{*}{$24 \mathrm{~h}$} & Inflammation & ++ & 0 & ++ & + & ++ & $\mathrm{N}$ \\
\hline & Necrosis & + & 0 & + & 0 & + & $\mathrm{N}$ \\
\hline
\end{tabular}

Scores as given in Table 2.

(N-Samples not available)

Table 4: Inflammatory infiltration and necrosis in brain in mice due to envenomation with different concentrations of $B$. ceylonicus (A) and B. caeruleus (B) venom.

\begin{tabular}{|c|c|c|c|c|c|c|c|}
\hline \multirow{3}{*}{$\begin{array}{l}\text { Time since } \\
\text { injection }\end{array}$} & \multirow{3}{*}{$\begin{array}{l}\text { Histopathological } \\
\text { feature }\end{array}$} & \multicolumn{6}{|c|}{ Venom Concentration } \\
\hline & & \multicolumn{2}{|c|}{$0.5 \mu g$} & \multicolumn{2}{|c|}{$1.0 \mu \mathrm{g}$} & \multicolumn{2}{|c|}{$2.0 \mu g$} \\
\hline & & A & B & A & B & A & B \\
\hline \multirow[t]{2}{*}{$1 \mathrm{~h}$} & Inflammation & 0 & 0 & + & + & + & 0 \\
\hline & Necrosis & 0 & 0 & + & + & + & 0 \\
\hline \multirow[t]{2}{*}{$3 \mathrm{~h}$} & Inflammation & 0 & 0 & + & 0 & + & 0 \\
\hline & Necrosis & 0 & 0 & + & 0 & + & 0 \\
\hline \multirow[t]{2}{*}{$6 \mathrm{~h}$} & Inflammation & + & 0 & + & 0 & + & 0 \\
\hline & Necrosis & + & 0 & 0 & 0 & + & 0 \\
\hline \multirow[t]{2}{*}{$12 \mathrm{~h}$} & Inflammation & + & 0 & 0 & 0 & + & $\mathrm{N}$ \\
\hline & Necrosis & + & 0 & 0 & 0 & + & $\mathrm{N}$ \\
\hline \multirow[t]{2}{*}{$24 \mathrm{~h}$} & Inflammation & + & 0 & + & 0 & + & $\mathrm{N}$ \\
\hline & Necrosis & + & 0 & + & 0 & + & $\mathrm{N}$ \\
\hline
\end{tabular}




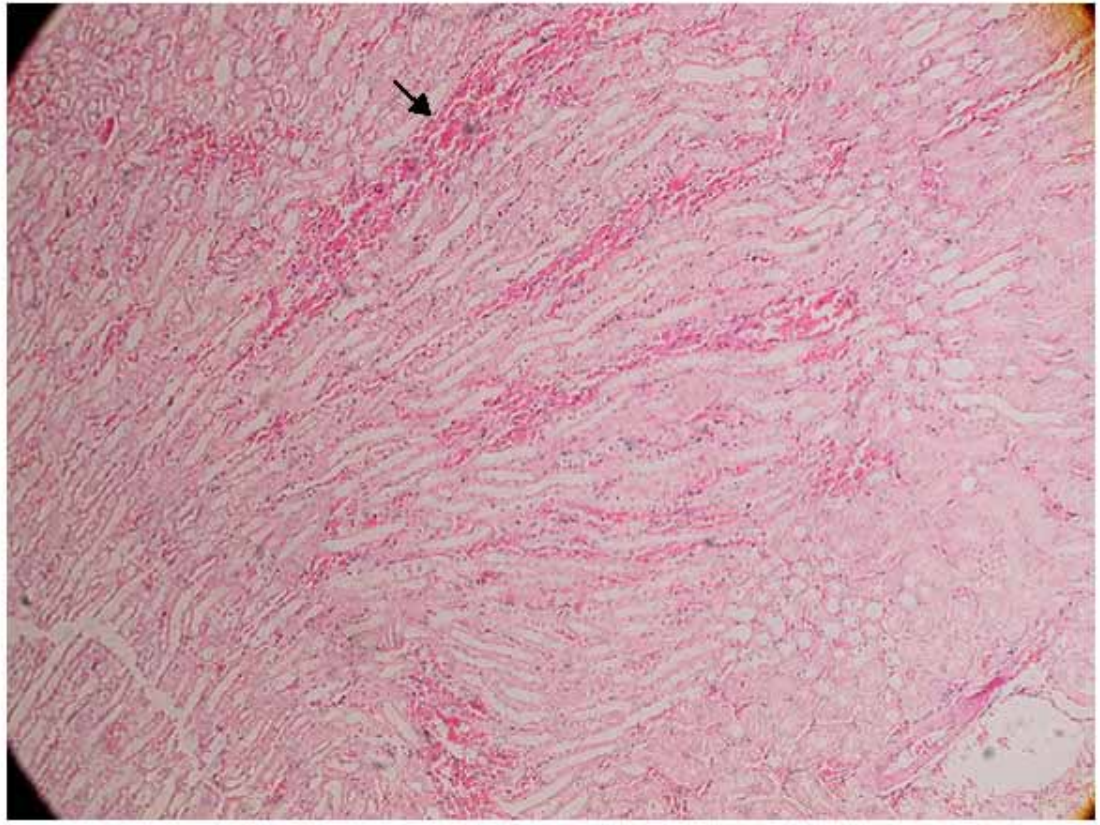

A (H\&E X $10 \times 10)$

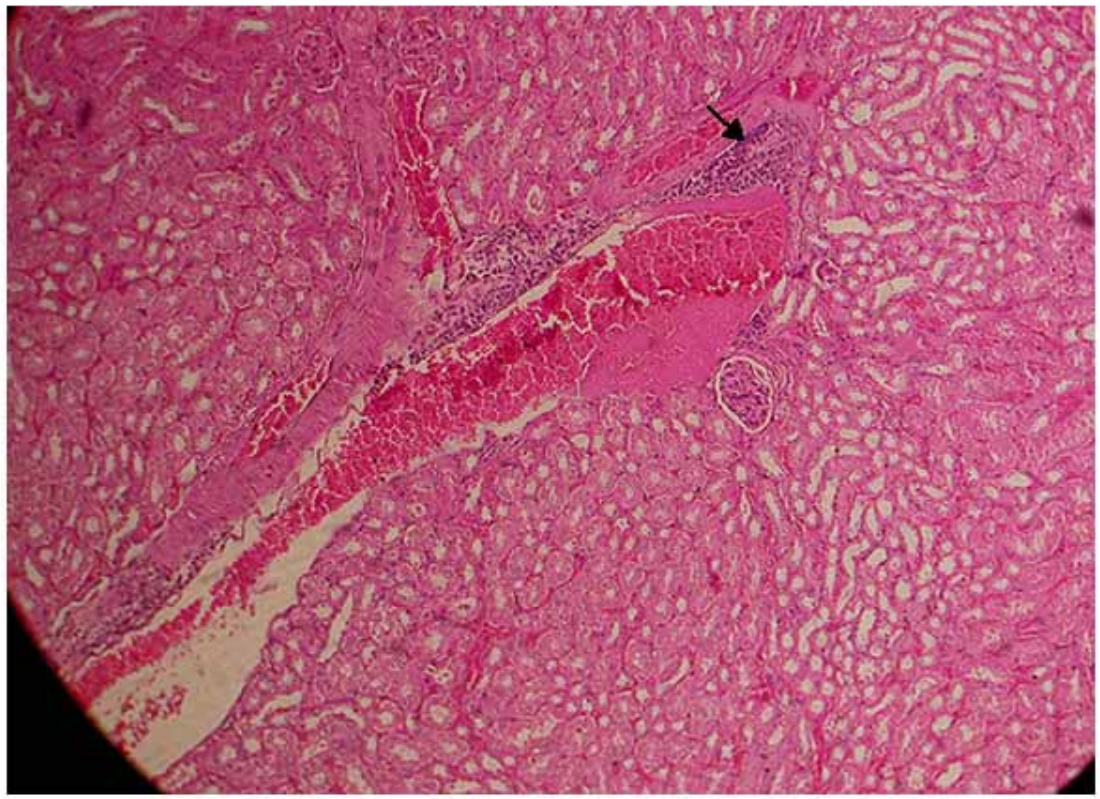

B (H\&E X $10 \times 60)$

Figure 3. Histopathological changes in kidney tissue of mice following envenomation with B. ceylonicus venom: (A) Congestion (arrow points to a congested interstitial vessel) and (B) Inflammation (arrow points to a perivenular inflammatory focus). 
Table 5. Inflammatory foci in kidney in mice due to envenomation with different concentrations of B. ceylonicus venom (A) and B. caeruleus (B) venom.

\begin{tabular}{|c|c|c|c|c|c|c|}
\hline \multirow{3}{*}{$\begin{array}{l}\text { Time since } \\
\text { injection }\end{array}$} & \multicolumn{6}{|c|}{ Venom Concentration } \\
\hline & \multicolumn{2}{|c|}{$0.5 \mu g$} & \multicolumn{2}{|c|}{$1.0 \mu \mathrm{g}$} & \multicolumn{2}{|c|}{$2.0 \mu \mathrm{g}$} \\
\hline & A & $\mathrm{B}$ & A & $\mathrm{B}$ & A & $\mathrm{B}$ \\
\hline $1 \mathrm{~h}$ & 0 & + & 0 & + & + & ++ \\
\hline $3 \mathrm{~h}$ & 0 & + & + & + & + & + \\
\hline $6 \mathrm{~h}$ & + & + & + & ++ & + & +++ \\
\hline $12 \mathrm{~h}$ & + & + & + & + & ++ & $\mathrm{N}$ \\
\hline $24 \mathrm{~h}$ & ++ & + & + & ++ & + & $\mathrm{N}$ \\
\hline
\end{tabular}

Sores as given in Table 2.

(N - Samples not available)

\section{DISCUSSION}

Histopathological changes were seen in the liver, brain and the kidney and those were of an acute toxic insult. Bungarus venom is rich in neurotoxins and certain neurotoxins like kappatoxin have its primary action in the central nervous system. This would be contributory to the presence of histopathological changes in the brain.

Post synaptic toxins get concentrated in the kidney at higher concentrations than in other tissues (Chang et al., 1979). On the other hand, the main route of excretion of elapid toxins is via kidney. These would explain the presence of congestion and inflammation in the kidneys. However, absence of neprhotoxic agents, vasculotoxins and haemotoxins would be the reason for the lack of necrosis in the kidneys. Liver, on the other hand being the primary detoxifying organ in the body could be affected by many types of toxic components in venom. However, since the affinity of neurotoxins is lower for the liver, it is possible that these changes are resulting from another toxic component in the venom other than neurotoxins.

Bungarus venom also contains phospholipases which show a range of different actions on different tissues. These enzymes hydrolyze phospholipids in the cell membrane and disturb the cell membrane activity (Iwanaga \& Suzuki, 1979). In the present study, the histopathological manifestations, mainly inflammatory and necrotic in nature could have occurred in response to the membrane damage caused by the action of these phospholipases. Viper venom, which is rich in phospholipases causes extensive tissue damage involving many organs.
Lower molecular weight toxins in krait venom are rapidly absorbed and fastly distributed through the blood stream (de Silva and Ranasinghe, 1983). Thus, toxic changes would appear in the target organs early. In this study the tissue changes were evident even at 1 hour after injection in the brain, kidney as well as the liver.

Hyaluronidase, is known to enhance tissue distribution of other toxins (Iwanaga \& Suzuki, 1979). Although Bungarus venom is not a rich source of hyaluronidase, $B$. candidus, the most venomous species in the genus Bungarus is known to have hyaluronidase activity in its venom (Pukrittayakamee et al., 1988). Thus, it is possible that $B$. ceylonicus and $B$. caeruleus also would contain hyaluronidase in their venom leading to a faster action. This could be the reason particularly with $B$. ceylonicus venom which has led to prominent tissue changes even at much lower doses.

In mice that were injected with $B$ ceylonicus venom, inflammatory infiltrates in the liver were pronounced even at the concentration of $0.5 \mu \mathrm{g}$ while with $B$. caeruleus this was seen with higher concentrations, $1.0 \mu \mathrm{g}$ and $2.0 \mu \mathrm{g}$. In the kidney, in both groups treated with $B$. caeruleus and $B$ ceylonicus venom, inflammatory changes were found to increase with concentration. Liver necrosis was seen only following administration of $B$. ceylonicus venom and was a consistent feature in mice at the dose of $2.0 \mu \mathrm{g}$. Administration of $B$. ceylonicus venom resulted in congestion, inflammation and necrosis in the brain at all concentrations, which was not seen with $B$. caeruleus venom. This suggests that the susceptibility of the tissues to effects of venom is different in the two species. Further histological studies with a correlation to the median lethal dose would be helpful in clarifying these issues. 
Since crude venom was injected, differences in venom composition could have contributed to the above differences. Differences in the phospholipase $A_{2}$ activity in the venom of the two species of snakes is a possibility which needs further biochemical studies with analysis of venom components. Necrosis of liver tissue produced by $B$. ceylonicus venom suggests the possibility of a cardiotoxin like substance in it as opposed to $B$. caeruleus venom. This is supported by the fact that cardiotoxin in cobra venom has a higher affinity towards the liver than the brain and kidney (Chang, 2003).

A previous study in India using $B$. caeruleus venom, has demonstrated haemorrhage and necrosis of proximal tubules of the kidney and petechial haemorrhages in the myocardium (Kiran et al., 2004) in addition to findings similar to the present study.

This study would be of importance in characterization of possible proteins in Bungarus venom as well as understanding their action in the process of development of a specific antivenom. In cases with suspected krait bites knowledge on changes in different tissues may be important. In addition, $B$. ceylonicus being an endemic species to Sri Lanka, understanding of its toxicology is of local importance.

\section{ACKNOWLEDGEMENTS}

We acknowledge Mr. P. G. L. Gunathilake, Technician, Department of Forensic Medicine, Faculty of Medicine for his assistance in preparation of light microscopic slides and Mr. Peiris for his assistance in collecting venom.

\section{REFERENCES}

Chang, C.C. (1979). The action of snake venom on nerve and muscle, In: C.Y. Lee (Ed), Snake venoms, Springer-Verlag Berlin Heidelberg, NewYork. Pp. 309-376.

Chang, L.S., Chung, C., Liou, J.C., Chang, C.W., Yang, C.C. (2003). Novel neurotoxins from Taiwan banded krait (Bungarus multicinctus) venom: purification, characterization and gene organization. Toxicon 42: 323-330.

Ciutat, D., Caldero, J., Oppenheim, R.W., Esquerda, J.E. (1996). Schwann cell apoptosis during normal development and after axonal degeneration induced by neurotoxins in the chick embryo. Journal of Neuroscience 16: 3979-3990.

de Silva, H.J., Ratnatunga, N., de Silva, U., Kularatne, W.N.S. and Wijewickrama, R. (1992). Severe fatty change with Hepatocellu;ar necrosis following bite by a Russell's viper. Transactions of the Royal Society of Tropical Medicine and Hygiene 86: 565.

Ranasinghe, L. (1983). Snakes and Ladders. Ceylon Medical Journal 28: 107-110.

Iwanaga, S. and Suzuki, T. (1979). Enzymes in Snake venom, In: C.Y. Lee (Ed), Snake venoms, Springer-Verlag Berlin Heidelberg NewYork. Pp. 61-158.

Kamiguti, A.S., Theakston, R.D., Sherman, N. and Fox, J.W. (2000). Mass spectrophotometric evidence for P-III/P-IV metalloproteinases in the venom of the Boomslang (Dispholidus typus) Toxicon 38: 1613-1620.

Kiran, K.M., More, S.S. and Gadag, J.R. (2004). Biochemical and clinicopathological changes induced by Bungarus caeruleus venom in a rat model. Journal of Basic Clinical Physiology and Pharmocology 15: 277-287.

Kularatne, S.A.M. and Ratnatunge, N. (2001). Autopsy study of Common Krait (Bungarus caeruleus) bite, Proceedings of the $4^{\text {th }}$ World Congress of Herpetology, Sri Lanka (Abstract).

Kumaranayake, C.S. (1971). Pathological findings in Viper bites. Ceylon Medical Journa, 16: $47-50$.

Peichoto, M.E., Teibler, P., Ruiz, R., Leiva, L. and Acosta, O. (2006). Systemic pathological alterations caused by Philodryas patagoniensis collubrid snake venom in rats. Toxicon 48: 520528.

Pukrittayakamee, S., Warrell, D.A., Desakorn, V., McMichael, A.J., White, N.J. and Bunnag, D. (1988). The hyaluronidase activities of some Southeast Asian snake venoms, Toxicon 26: 629-637.

Sheriff, M.H.R. (1983). Renal disease due to snake bite and its management. Ceylon Medical Journal 28: 190-198. 
Sitprija, V. (2006). Snake bite Nephropathy. Nephrology 11: 442-448.

Soe, S., Win, M.M., Htwe, T.T., Lwin, M., Thet, S.S. and Kyaw, W.W. (1993). Renal histopathology following Russell's viper (Vipera russelli) bite. Southeast Asian Journal of Tropical Medicine and Public Health. 24: 193197. 